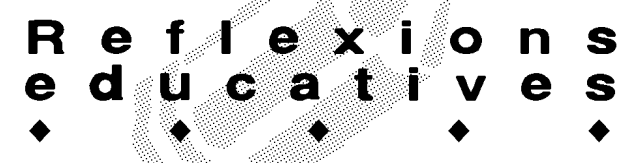

\title{
LES IDEES CIENTÍFIQUES DELS INFANTS I L'ENSENYAMENT DE LES CIÈNCIES A L'ESCOLA PRIMÀRIA
}

\author{
Jordi Martí i Feixas. Departament de Ciències i Ciències Socials. Facultat d'Educació. Universitat de Vic
}

\section{Presentació}

En aquest article presentem unes reflexions breus en relació amb tres elements que considerem bàsics en les estratègies de treball a l'aula en l'àmbit de l'ensenyament de les ciències a l'escola primària. Es tracta de la presència de la realitat a l'aula, de la importància de les idees dels nens i nenes, i del procés d'evolució d'aquestes idees.

\section{L'ensenyament de les ciències: una història de canvis}

Al llarg de la història de l'ensenyament de les ciències -que al nostre país s'inicia el 1901, moment en què passa oficialment a formar part de tots els nivells de l'educació obligatòria (BERNAL, 2001)-, s'han viscut molts canvis de finalitats, de continguts i de metodologies. Aquests canvis sovint han afectat més els plantejaments teòrics que no pas les aplicacions pràctiques, i han estat fruit de les influències i aportacions fetes des de la pedagogia, la psicologia, la filosofia, la història i la sociologia de la ciència, les polítiques educatives, etc.

D'aquesta llarga trajectòria en podem aprendre algunes coses. En primer lloc, la mateixa evolució ja és interessant perquè ens mostra que els plantejaments sobre l'ensenyament-aprenentatge de les ciències van canviant, fruit de múltiples i diverses aportacions, tant teòriques com derivades de l'anàlisi de la pràctica.

En segon lloc, podem constatar un canvi important en les finalitats. Així, s'ha passat de la idea de formar els futurs científics a considerar l'alfabetització científica de tota la població com a objectiu fonamental. Formar els futurs científics era un objectiu bàsic a la postguerra mundial, ja que la fe en el progrés de la ciència i la tensió que es vivia entre les dues grans potències feien necessària la millora de la formació dels científics i l'augment del seu nombre. Considerar l'alfabetització científica de la ciutadania com a finalitat a assolir és fruit del model comprensiu de l'escola actual i de l'ampliació de l'escolaritat obligatòria, però també de l'acceptació de la importància cultural de la ciència. L'alfabetització científica passa per l'adquisició de coneixement científic i pel seu ús, però també passa per la comprensió de la ciència com una activitat humana complexa, caracteritzada per una determinada forma de pensar i actuar. Si adoptem aquesta finalitat com a objecte de l'educació científica, és fàcil veure que la ciència a l'aula no es pot fer de qualsevol manera, perquè no es tracta d'adquirir multitud de coneixements superficials, sinó que es tracta de, per una banda, aprofundir en les aportacions més significatives de la ciència, tant històriques com recents, per tal que això permeti a les persones poder reflexionar sobre què els diuen aquests coneixements en relació amb un mateix $i$ al seu entorn, i per altra banda, aprendre a mirar i a interrogar el món des dels ulls de la ciència, la qual cosa suposa desenvolupar unes actituds i uns procediments característics del pensament científic.

També s'han produït canvis en les orientacions metodològiques, fruit de les aportacions fetes des de la pedagogia o des de la psicologia. Des de la reflexió pedagògica podem pensar en les aportacions fetes a principis de segle pel moviment de l'Escola Nova -destacant el protagonisme dels infants o bé considerant el medi proper com a objecte d'estudi- que al nostre país van influir en les propostes d'autores com Margarida Comas - Rosa Sensat i van inspirar les propostes renovadores dels Moviments de Renovació Pedagògica. També cal destacar les aportacions fetes des de la psicologia -amb autors com Piaget, Gagné, Ausubel o Vigotsky-introduint conceptes i models teòrics sobre els processos d'aprenentatge que, al seu torn, han influït sobre els models d'ensenyament. En aquest procés hem après més sobre què no funciona que no pas sobre què cal fer, i probablement això sempre serà així. A grans trets s'ha proposat passar de metodologies d'aula centrades en la transmissió del coneixement conceptual, a d'altres centrades en l'activitat de l'alumne, entenent aquesta activitat com tot allò que contribueix a la construcció personal del coneixement científic. Una de les aportacions més importants en aquest àmbit, com destaquem més endavant, ha estat la recerca feta entorn de les idees científiques dels infants i els joves.

Tenint en compte aquests moviments voldríem introduir, i treballar una mica, tres aspectes que considerem bàsics per a l'ensenyament-aprenentatge de les ciències a primària en aquests moments. 


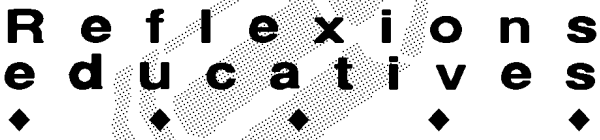

Tres aspectes importants per a l'ensenyamentaprenentatge de les ciències a l'escola primària

Sigui quina sigui la manera com es desenvolupa el treball a l'aula, sempre respon a unes determinades finalitats i, en el cas de l'educació científica, respon també a una determinada manera de concebre la ciència i l'aprenentatge científic. En aquest article ens situem en una concepció de la ciència que la considera una activitat humana, que té per objectiu, entre d'altres, generar coneixement sobre la realitat (ECHEVARRÍA, 1995); i ens situem en un model d'aprenentatge que considera que el coneixement es construeix a partir del diàleg entre el que ja se sap i les noves idees $i$ experiències que es vehiculen a l'aula. Per això, ens plantegem un model d'educació científica que permeti desenvolupar estratègies de treball a l'aula que se centrin a promoure l'evolució de les idees dels alumnes, tot aplicant allò que caracteritza l'activitat i el pensament científics (HARLEN, 1998, 2000).

Aquest plantejament deriva molt directament d'una de les aportacions més significatives que s'han fet en relació amb l'ensenyament-aprenentatge de les ciències: l'existència i importància pedagògica del que podem anomenar les idees científiques dels infants (DRIVER, GUESNE i TIBERGHIEN, 1989; OSBORNE i FREYBERG, 1995; SPACE RESEARCH REPORTS, 1990-
98). Podem concebre, doncs, l'educació científica com l'espai on s'aprendran alguns dels models explicatius sobre la realitat que els científics han anat construint al llarg del temps $i$, al mateix temps, com un entorn que permetrà iniciar-se en l'activitat científica, és a dir, en les formes de pensar, de fer, de parlar i de sentir que els científics utilitzen per construir coneixement (ARCÀ, 1990; HARLEN, 1998, 2000; PUJOL, 2003). Entès d'aquesta manera, l'aprenentatge científic és un procés en el qual es produeix una evolució de les idees dels infants, fent-se cada cop més properes a les científiques. Aquest procés es mostra a l'esquema de la figura 1.

Des d'aquest plantejament hi ha tres elements fonamentals que donaran forma al treball a l'aula: a) la realitat, és a dir, els objectes i fenòmens que intentem explicar; b) les idees dels nens i nenes; c) el procés d'evolució d'aquestes idees.

Parlem una mica més de cadascun.

a) La realitat, els seus objectes i fenòmens

El món físic i el món viu són el punt de partida de l'activitat científica. Des de la mirada de la ciència la realitat està conformada per objectes-sistemes i per fenòmens que pretenem comprendre. Els objectes són distribucions espacials de matèria, energia o informació (WAGENSBERG, 2004). En la ciència contemporània, tanmateix, cada cop més es considera que la realitat

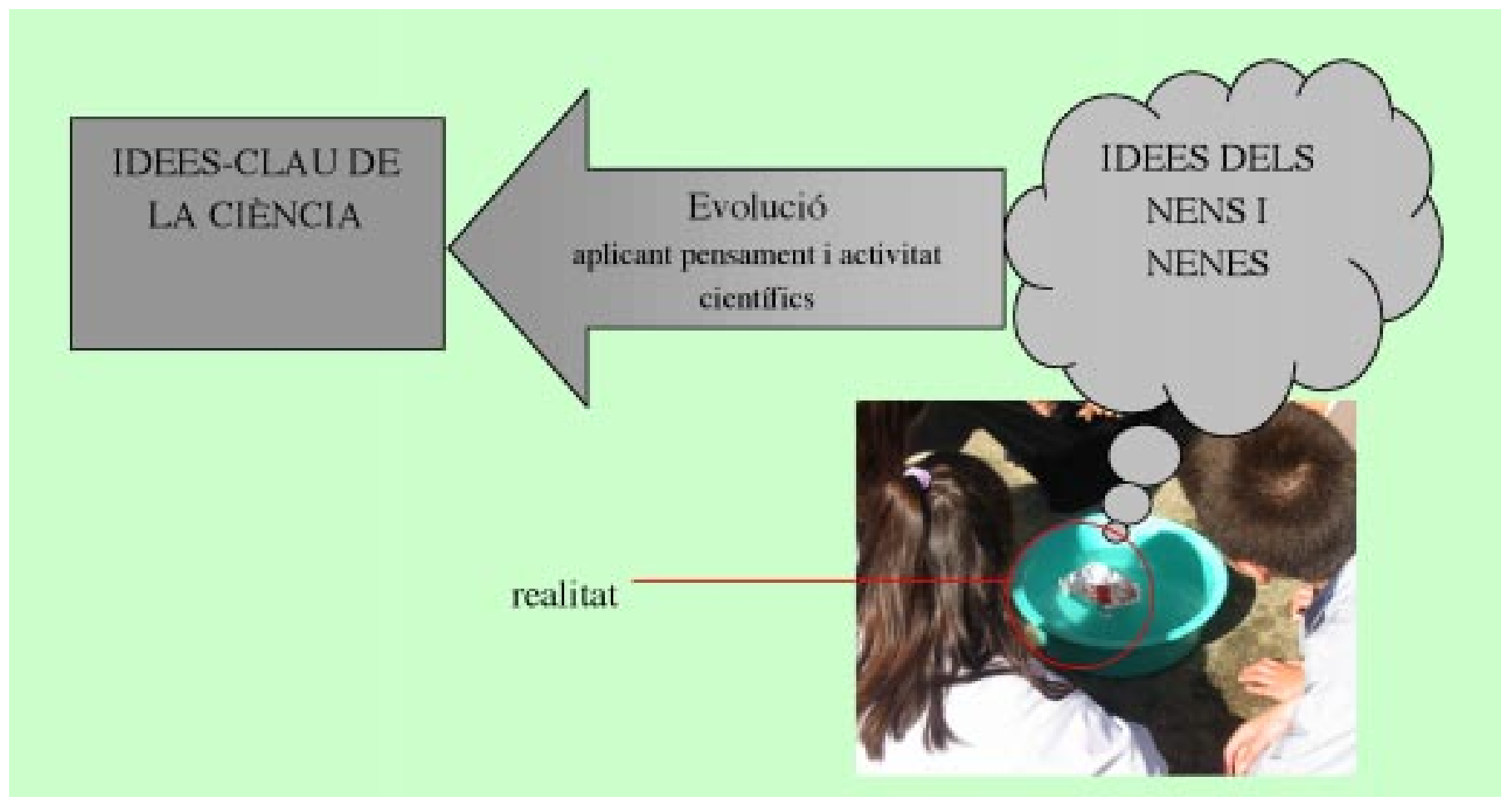

Figura 1. Esquema de l'evolució en la formació de les idees-clau de la ciència. 


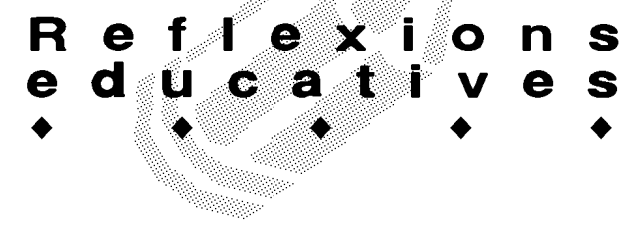

està formada per sistemes integrats els uns en els altres, considerant un sistema com un conjunt de parts heterogènies la interacció de les quals configura un tot organitzat. La consideració dels objectes com a sistemes no és poc important des d'un punt de vista de comprensió de la realitat, perquè l'estudi d'un sistema no és igual que l'estudi d'un objecte. Entendre la realitat com un conjunt de sistemes ens obliga a estudiar les parts, però sobretot les interaccions organitzadores i reguladores entre les parts; entendre el món com una col·lecció d'objectes, per contra, podria conduir només a l'anàlisi i la descripció de les parts que el constitueixen. Els fenòmens són canvis temporals dels objectes-sistemes -la rotació d'un planeta, el creixement d'una planta, l'expansió d'un gas, etc.-. Sobre tots aquests objectessistemes i fenòmens la ciència ha aportat coneixement en forma de models explicatius, els quals incorporen conceptes, principis, evidències, etc.

El contacte amb la realitat, amb el món dels objectessistemes i els fenòmens és bàsic per a l'activitat científica i també ho ha de ser per a l'activitat científica escolar. En quins moments i de quines maneres es pot portar a terme aquest contacte? En la majoria de casos el contacte dels científics amb la realitat és fruit de la necessitat de comprovació d'idees o de l'aplicació real d'experiments pensats, i per tant sol ser posterior a les idees; a vegades, per contra, el contacte amb la realitat a través de l'observació i l'experimentació genera nous estímuls i nous interrogants. A l'escola el contacte amb la realitat hauria de perseguir aquestes dues funcions. Per una banda, pot produir-se quan volem comprovar una idea, però també pot produir-se perquè volem estimular el pensament mostrant als alumnes, sobretot als més petits, objectes o fenòmens que desconeixen o coneixen poc. Això vol dir que l'observació i manipulació de la realitat s'ha de plantejar no només com una activitat de descripció i recollida d'informació, sinó com un espai en el qual s'estimuli el pensament, la qual cosa passa necessàriament per la formulació de preguntes: ¿quina pot ser la causa que això funcioni o es comporti d'aquesta manera?, ¿què passaria si...? Per exemple, portar a la classe diferents productes i olorar-los no hauria de servir només per descriure les sensacions obtingudes ni per conèixer els adjectius que podem usar per descriure les diferents olors, sinó per plantejar-se com és possible que el nostre cos detecti les olors, per pensar sobre què deu ser l'olor, etc. Descriure amb detall la morfologia d'una llavor i dibuixar-la no aporta gran cosa si no serveix per preguntar-se sobre la seva forma o la seva mida, sobre què hi ha al seu interior, etc. Amb aquestes preguntes no perseguim una resposta immediata, ni tampoc "correcta", el que perseguim és estimular el pensament, mobilitzar les idees dels nens i nenes i posar-les en joc per començar-hi a treballar.

Al llarg de la història de la ciència el contacte amb la realitat ha millorat molt amb la utilització de diferents instruments d'observació i de mesura. Almenys alguns d'aquests instruments caldrà introduir-los durant la primària, coneixent-ne les seves possibilitats i limitacions.

Però el contacte amb la realitat no és suficient, perquè la finalitat de la mirada científica és intentar explicar-la. Com diu la dita: "qui no sap el que busca no comprèn el que troba". És aquí on entra en joc el segon element, i segurament el més important, d'una classe de ciències, les idees dels infants sobre la realitat objecte d'estudi.

\section{b) Les idees dels nens i nenes}

Una de les aportacions més importants de la investigació didàctica ha estat, sens dubte, el reconeixement de la importància de les idees dels infants en el procés d'aprenentatge de la ciència (DRIVER, GUESNE i TIBERGHIEN, 1989; OSBORNE i FREYBERG, 1995; DRIVER, 1999). Lluny de considerar els infants com una ment en blanc, actualment sabem que tots són capaços de construir-se representacions dels objectes i fenòmens que se'ls proposa estudiar, explicacions sobre el funcionament de les coses i atribucions de significat a termes científics d'ús habitual i, a més a més, reconeixem el valor d'aquestes idees. En la majoria de casos les idees individuals tenen característiques comunes que ens permeten pensar en l'existència d'unes concepcions que, si bé no són universals, sí que estan molt generalitzades. De les idees dels infants se n'havien dit inicialment errors conceptuals, però actualment aquest terme ha caigut en desús, ja que, malgrat que habitualment difereixen de les explicacions científiques acceptades, en cap cas les podem considerar errors. El fet que difereixin de les idees acceptades per la ciència només demostra que les explicacions científiques tenen poc a veure amb el sentit comú, i que sovint són fruit d'una mirada imaginativa i creativa de la realitat.

Les idees dels infants s'originen per la curiositat i la necessitat naturals per explicar-se allò que s'esdevé, i estan molt condicionades per les experiències personals, l'ensenyament i els materials educatius, els mitjans de comunicació, la cultura popular, etc. A més a més, es construeixen a partir de les estratègies de raonament de les quals disposa cada nen o nena.

La investigació didàctica ha posat de manifest una sèrie de característiques d'aquestes idees dels nens i nenes, que de manera resumida serien:

- Són personals, però moltes vegades són compartides per individus de diferents contextos socials, edats o sexes. 


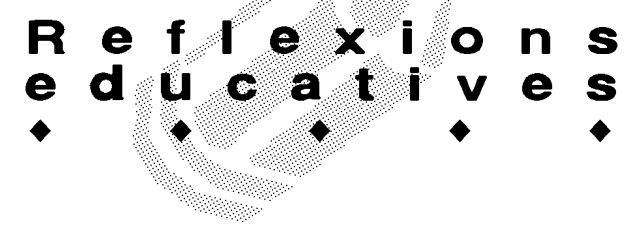

- Influeixen les observacions i interpretacions que els nens i nenes fan de la realitat.

- Tenen un cert grau de coherència interna segons la lògica dels infants, encara que a vegades també poden ser produïdes ad hoc.

- Són estables i persistents, i per tant, difícils de canviar amb les estratègies convencionals d'ensenyament, ja que els nens i nenes els atribueixen molt valor; sovint també costen de canviar malgrat l'evidència en contra, ja que, o bé no tenen en compte aquesta evidència o bé la modifiquen i l'obliguen a encaixar en la idea.

- Sovint s'assemblen a concepcions científiques vigents en altres èpoques.

- Interaccionen amb el nou coneixement i no es pot predir ni generalitzar què en resultarà d'aquesta interacció.

Des d'un punt de vista didàctic, les idees dels infants tenen unes implicacions clares, ja que ens obliguen a considerar que els nens i nenes arriben a les aules amb una sèrie de coneixements i d'habilitats - pràctiques, de raonament, etc.- amb els quals afrontaran les idees $i$ informacions que s'hi vehiculin. Per tant, cal tenir-los en compte en el disseny de la seqüència d'activitats, i això suposa planificar activitats d'exploració que permetin als nens i nenes explicitar les seves idees, compartirles, discutir-les i contrastar-les amb les dels seus companys i companyes i amb l'evidència disponible. Igualment, aquestes activitats d'exploració han de servir als mestres per avaluar la distància que hi ha entre les idees dels alumnes i la idea clau de la ciència a la qual es vol arribar, així com les principals dificultats que es trobaran en la interacció de les unes i les altres.

S'han fet inventaris d'aquestes idees (DRIVER, 1999; SPACE PROJECT REPORTS, 1990-98) que són molt interessants per als mestres, ja que els permetran conèixer quines seran, probablement, les idees científiques que els seus alumnes manifestaran en relació amb un determinat fenomen. Recentment en alguns països s'han començat a elaborar materials per als mestres que parteixen de l'exploració de les idees dels nens i que presenten propostes d'activitats per al seu desenvolupament (NUFFIELD FOUNDATION, 1997).

Les idees dels alumnes, doncs, són importants almenys per dues raons: 1) la producció d'idees i la seva presentació pública són aspectes centrals del desenvolupament de la comprensió científica d'un fenomen, i 2) la producció i l'avaluació de les idees juga un paper central en l'activitat científica i en l'aprenentatge de les ciències.

Per gestionar les idees dels infants a l'aula caldrà, en primer lloc, analitzar-les i per això haurem d'establir uns criteris d'anàlisi. Per exemple, podem plantejar-nos el seu origen i així ens podem trobar idees: 1) derivades d'un nivell d'experiència inadequat, 2) basades en percepcions limitades, 3 ) focalitzades en un sol aspecte del fenomen ignorant-ne d'altres, 4) conseqüència d'un error de raonament, 5) lligades a un context molt particular, 6) basades en una mala comprensió o en un ús quotidià dels termes científics, 7) derivades de l'aplicació de models incorrectes.

El coneixement i l'anàlisi de les idees dels nostres alumnes en relació amb els fets científics que estem estudiant esdevenen el punt del qual hem de partir en el disseny d'activitats, el qual sempre ha de tenir per objectiu fer-les evolucionar i aproximar-les a les científiques. Aquest procés d'evolució és el tercer aspecte que volem destacar.

c) L'evolució de les idees dels infants: desvetllar la curiositat reflexiva

Des del plantejament que estem proposant, el punt de partida no són els coneixements tal com es presenten en una disciplina científica, sinó les maneres d'explicarlos dels nens i nenes. El treball a l'aula, per tant, s'ha de centrar en el procés d'evolució d'aquestes idees, i per això cal tenir en compte una sèrie d'aspectes que poden ajudar a realitzar aquest procés.

\section{Aspectes a tenir en compte per ajudar els infants en el procés evolutiu de les seves idees}

- Tenir clar on es vol arribar

El model transmissiu de treball a l'aula sovint es basa en la introducció de conceptes -fotosíntesi, digestió, gas, dissolució, reproducció, etc.-. Tots aquests conceptes científics representen objectes o processos de la realitat, i com a tals s'han anat construint amb el temps. Començar per aquí és, per tant, començar la història pel final.

En el model que es presenta s'entén que el docent ha de tenir clar a quines idees-clau vol arribar o quines idees-clau es proposa treballar. Per exemple, la cosmologia contemporània (REES, 2002) ens ha aportat una idea molt interessant sobre el món que ens envolta, que podríem formular com: "la matèria s'organitza sense la intervenció de cap element extern". Aquesta és una idea molt potent de la ciència actual, i malgrat que no ho sembli, potser és més fàcil jugar a pensar sobre aquesta idea amb els nostres alumnes que no pas comprendre la teoria del Big Bang que se'ls explica en un llibre de text.

Es tracta, doncs, de seleccionar, per a cada model conceptual de la ciència que es vol treballar, unes poques idees-clau, clarament formulades, que serveixin al mestre com a horitzó i com a referència per a la interpretació de 


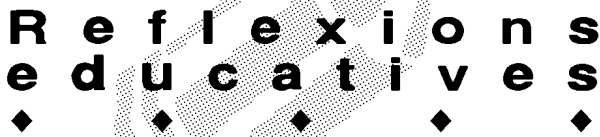

les idees dels nens. Posem un parell d'exemples.

Quan es treballa sobre el procés de germinació d'una llavor, es pot considerar que una idea fonamental és arribar a comprendre que: "la llavor està feta d'una part viva que pot créixer, unes substàncies de reserva i una capa de protecció"; o bé que: "el procés de germinació depèn de condicions externes i internes", i encara: "la llavor, en les primeres fases de desenvolupament no necessita sals minerals del sòl". Algunes idees importants a assolir quan es treballa sobre el sentit de l'olfacte serien: "les olors són partícules molt petites que circulen per l'aire"; "aquestes partícules són captades per uns receptors especialitzats"; "aquests receptors envien la informació al cervell a través d'un nervi".

Aquestes idees són el final, no l'inici. L'inici són les idees dels alumnes sobre les llavors, la germinació o les olors, no les de la ciència. Així, per exemple, en relació amb un dels temes mencionats en el paràgraf anterior, ens trobem que molts alumnes consideren que una llavor per germinar necessita sals minerals del sòl. Si partim d'aquesta idea, ens serà molt útil el treball clàssic de fer germinar llavors a l'aula, perquè ara aquest treball se'ns planteja com un repte a la idea que els nens manifesten. Si les llavors són capaces de germinar en cotó fluix, aleshores: ¿necessiten o no necessiten sals minerals? Si la planta que hem obtingut no la traslladem a un test, es mor; aleshores: ¿una planta adulta necessita o no necessita sals minerals?

- Explorar la realitat per explorar les idees sobre la realitat

Com ja s'ha dit, explorar la realitat és bàsic per a l'ensenyament-aprenentatge de les ciències. Malauradament massa sovint les classes de ciències es fan sense anar, en un moment o altre, a la realitat, amb la qual cosa es transmet una imatge molt pobra de l'activitat científica; una imatge que fa concebre la ciència com un coneixement acabat, indiscutible, formulat en un libre i només apte per a experts.

No deixa de ser curiós que això sigui així, donat que hi ha moltíssims materials que ens mostren experiències fàcils de fer a l'aula o materials manipulables que podrien servir com a estímul al pensament. Per exemple, la bossa que s'infla en un pot de buit, els grills que es barallen al terrari que tenim a l'aula, la planta que es gira

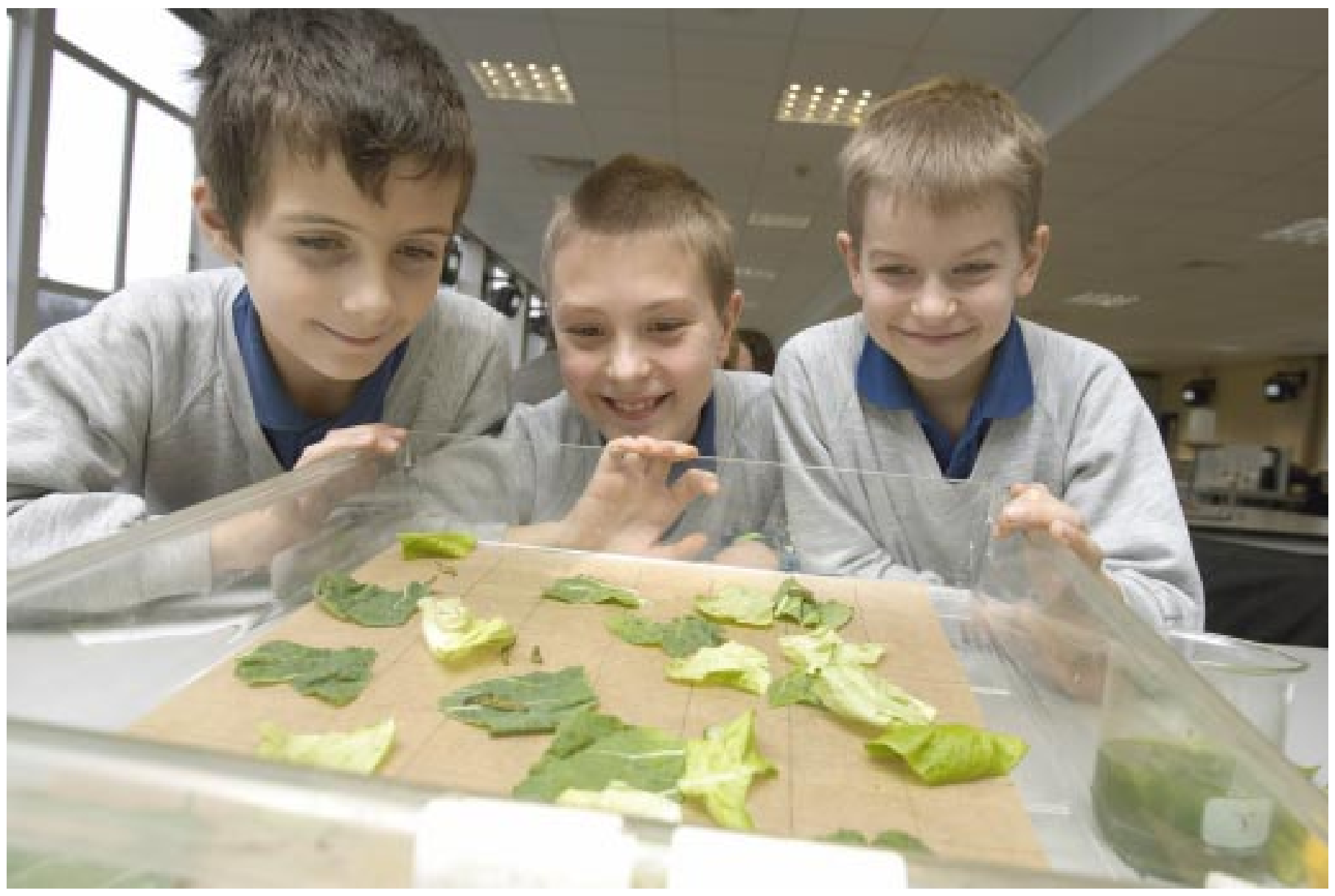




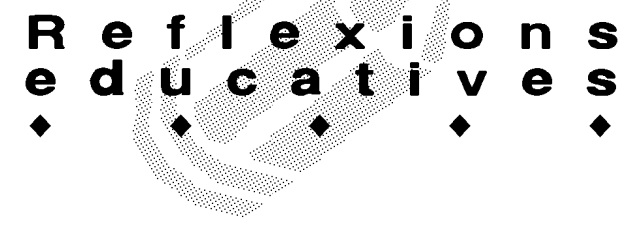

cap a la llum, les ombres que es formen al col-locar un pal al pati de l'escola, el glaçó que es fon més a poc a poc quan està embolicat amb roba de llana que no pas quan està a la intempèrie, la sal que "desapareix" quan la barregem amb aigua, la bombolla de sabó que sempre és esfèrica, etcètera, etcètera.

No es tracta de fer experiments i ja està. Es tracta d'observar la realitat o provocar-la perquè actuï i ens permeti formular-nos alguns interrogants: ¿per què s'inflen la bossa i el globus?; ¿com ho sap un grill on és l'altre grill?; ¿com s'ho fa la planta per saber on és el Sol?; ¿de què depèn el canvi en la direcció i la llargada de l'ombra del pal?; ¿per què ha trigat més a fondre's el glaçó embolicat?; ¿podem tornar a recuperar la sal que ha desaparegut?; ¿com és que les bombolles de sabó, les fem com les fem, sempre són esfèriques? Cada nen i cada nena tindrà elements per pensar sobre aquests problemes, perquè el que perseguim no és la resposta correcta, sinó la construcció de models explicatius que funcionin i que siguin pròxims als punts de vista de la ciència.

Quan no apareix cap idea, aleshores és el moment d'introduir-ne per part del professorat, però sense imposar-la, sinó posant-la a prova com ho faríem amb les dels nens i nenes. Així, per exemple, si no apareix cap idea en relació amb el problema de la bossa que s'infla, podem plantejar als infants de provar d'imaginarse l'aire com un conjunt de partícules en moviment continu i veure si aquest model de gas funciona per explicar el que veiem al pot de buit. $O$ bé quan els nens i nenes de primària no saben com explicar el creixement de les ungles del peu a partir del que mengem, haurem d'ajudar-los a imaginar-se i a representar-se mentalment els nutrients dels aliments com a peces fonamentals de la nostra composició química que viatgen per l'interior del cos.

- Estimular el joc de les idees a partir de preguntes mediadores i centrar la investigació a partir de preguntes investigables

Amb el que acabem de dir en els paràgrafs anteriors es posa de manifest la importància de les preguntes per a l'ensenyament-aprenentatge de les ciències. Les preguntes sempre han de ser benvingudes a l'aula, i això ho hem d'afirmar rotundament perquè la història de la ciència ens mostra com l'empenta interrogadora dels científics i la confiança en les capacitats humanes per trobar respostes útils han sigut el motor de l'activitat científica.

La curiositat que els alumnes manifesten de manera espontània pot anar a la deriva si no es concentra a través de la formulació de preguntes. Els problemes interessants no existeixen per ells mateixos, sinó que els creem a partir de les preguntes. Des de la pedagogia hi ha hagut moltes veus que han defensat la importància de complementar l'educació de la pregunta i l'educació de la resposta. Així. per exemple. el pedagog brasiler Paulo Freire afirma: "L'error d'una educació de la resposta no està en la resposta, sinó en la ruptura entre aquesta i la pregunta. L'error consisteix en el fet que la resposta és proclamada independentment de la pregunta que la provocaria. D'igual manera, l'educació de la pregunta estaria equivocada si la resposta no es percebés com a part de la pregunta" (FREIRE, 1997).

No totes les preguntes són iguals ni condueixen a les mateixes accions per respondre-les. Per això cal saber reconèixer-les i distingir-les, i saber quan i com usar-les. De preguntes n'hi ha de molts tipus, però "per a la ciència, les preguntes significatives són aquelles que sorgeixen del diàleg entre la teoria i l'observació dels fenòmens, que possibiliten establir diferències, refutar, substituir o ampliar l'abast de les explicacions científiques" (MÁRQUEZ, 2004). Hi ha moltes maneres de categoritzar les preguntes, i n'hem escollit dues: en relació amb la mena d'explicació a què condueixen i en relació amb la seva productivitat. En relació amb la mena d'explicació a què condueixen, en podem distingir tres grans categories: a) les preguntes descriptives, que es plantegen per descriure un fenomen i condueixen a construir descripcions; b) les preguntes causatives, que es plantegen per buscar les causes o les raons d'un fenomen i condueixen a explicacions causals; c) les preguntes predictives, que es plantegen per determinar el comportament d'un fenomen en unes noves condicions i condueixen a construir prediccions. Així, doncs, no és el mateix preguntar-se: ¿com és un cuc? o preguntarse: ¿per què és d'aquesta manera?, o ¿què farà el cuc si...? Tant en la ciència dels científics com en la ciència escolar no n'hi ha prou amb preguntes descriptives, ja que, tot i que una bona i àmplia descripció d'un objecte o fenomen és absolutament imprescindible, la simple descripció no ens diu res sobre les causes, i la ciència sempre intenta comprendre les causes o raons dels fenòmens de la realitat. Per tant, caldrà introduir sempre preguntes sobre el com i el perquè a més a més de sobre el què. Segurament en aquests moments, si analitzem la realitat de les aules, ens adonarem que s'està fent una ciència molt descriptiva. Els nens i nenes passen moltes hores descrivint coses -animals, roques, canvis químics...- però la construcció d'explicacions és gairebé patrimoni exclusiu dels docents. Sembla com si inconscientment penséssim el següent: "tu descriu bé el que veus o el que passa, que jo ja t'explicaré per què passa".

Les preguntes també les podem categoritzar en 


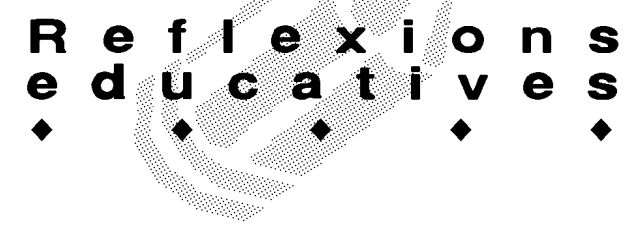

relació amb la seva productivitat, tot assenyalant-ne dos tipus contraposats: les preguntes productives i les preguntes reproductives. Les primeres conviden a fer noves observacions, a encetar processos més o menys complexos d'investigació, mentre que les segones es poden resoldre simplement reproduint el discurs del llibre de text o l'explicació del mestre. Les preguntes productives solen ser obertes i centrades en la persona, la qual cosa fa que no tinguin una solució única i predeterminada, i atorguen una importància real a les idees pròpies de l'individu, mentre que les reproductives solen ser tancades i centrades en el tema, és a dir, tenen una solució única i només esperen la reproducció d'una informació preestablerta.

Disposar d'un ampli repertori de preguntes és bàsic per a un/a mestre/a, i això ens obliga a nosaltres mateixos a ser curiosos i a interrogar-nos. Massa sovint aquestes actituds que es demanen als nens i nenes no es manifesten en els mateixos mestres. Cal perdre la por a les preguntes perquè sentir-se còmode en el món de les preguntes actua com a estímul, i a més ens fa còmplices de l'activitat investigadora dels alumnes.

Si tenim clara la importància de les preguntes, encara no hem acabat la feina perquè allò més difícil de la seva gestió a l'aula és saber com reformular-les perquè esdevinguin preguntes investigables. Moltes vegades això es pot fer transformant les preguntes formulades amb un per què en preguntes formulades amb un com-icom afecta la llum al creixement d'una planta? en lloc de ¿per què les plantes necessiten llum?-. Aprendre a construir preguntes investigables també permetrà adonar-se que la ciència no pot respondre totes les preguntes i que n'hi ha que caldrà respondre-les des d'altres aproximacions.

- Ajudar a desenvolupar les pròpies idees contrastantles amb l'evidència disponible

Una regla fonamental de la ciència és el contrast de les idees que genera amb l'evidència empírica disponible. Per això cal assegurar-se que els alumnes sempre comprovin, contrastin i avaluïn les seves pròpies idees, ja que si no es fa això, fàcilment les idees queden intactes. Per això primer cal que les idees s'expressin en forma d'explicacions comprovables. Quan, per exemple, un alumne afirma que "el gel es fon perquè està a fora" podem convertir aquesta afirmació en una predicció comprovable: "si fos a dins, no es fondria?". Aquesta predicció pot ser fàcilment investigada i la idea replantejada tot centrant el problema no en el lloc, que és on l'alumne ha vist que passava el fenomen, sinó en la temperatura, que sabem que és la causa del fenomen. Si això ho fem amb tota la classe i podem contrastar altres idees, pot ser que mobilitzem les idees "poc científiques" d'alguns alumnes perquè en veuran d'altres d'al- ternatives que funcionen millor enfront de l'evidència.

- Aportar noves evidències

A vegades el problema per a l'evolució de les idees dels nens i nenes és que el seu repertori d'experiències és massa limitat. Per tant, caldrà proposar activitats que ampliïn el ventall de tipus de materials, d'éssers vius, de fenòmens, etc., que formen part del seu repertori d'experiències. Sovint aquestes noves evidències repten les idees dels alumnes $\mathrm{i}$ els obliguen a ser més curosos en les seves generalitzacions. Així potser passaran de la idea que "les coses de fusta suren" a la idea que "gairebé tota la fusta sura, però no tota"; de la idea que "el so viatja per l'aire" a la idea que "el so també viatja pels sòlids i els líquids".

Sovint les idees dels infants ens indiquen l'experiència que falta, i estar atent al que expressen ens permetrà pensar en el tipus de noves evidències que els hem d'aportar. Per exemple, la idea que el rovell es forma dins el metall i que surt a la superfície es pot qüestionar tallant un clau. Això és més difícil quan l'experiència que cal aportar és sobre aspectes que no poden ser directament observats, per exemple l'interior del cos humà. En aquests casos caldrà optar per altres recursos: llibres, visites, models introduïts pel mestre, etc.

- Discutir el significat dels mots i d'altres representacions

Els nens i nenes no sempre usen els termes científics amb el mateix significat o profunditat de sentit propis dels docents o els científics. Així, per exemple, l'ús del terme fotosíntesi per part d'un alumne no suposa que en la representació mental que es fa d'aquest procés hi intervinguin tots els elements que el model científic té en compte. Per això és indispensable que els docents estimulem els nens i nenes a clarificar el significat dels mots que utilitzen, a exemplificar-los, etc., per podernos fer una representació del que volen dir i de la correcció en l'ús científic del terme.

En aquest mateix sentit pensem que la introducció dels termes científics no té per què estalviar-se. Així, dir que la sal ha desaparegut, en lloc de dir que la sal s'ha dissolt, no canvia gaire el sentit profund del fenomen per a un nen o nena que l'observa. El problema no és tant el terme que es fa servir com la representació que l'acompanya. Desaparèixer, a la ment d'un nen, pot tenir un significat clar i allunyat de la idea de dissolució. Dissoldre's pot no tenir un referent clar per a la ment d'un alumne, però justament ajudar a construir aquesta representació és la feina que pertoca als mestres.

- Estimular la comunicació usant diferents llenguatges $i$ habilitats comunicatives

L'activitat científica no es limita al treball de camp o de laboratori, sinó que es comunica, es fa pública en 


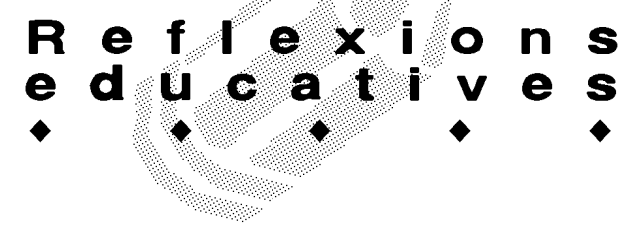

congressos o en articles científics. Això és així perquè el coneixement científic és eminentment un coneixement públic i compartit. Per tant, és indispensable que la comunicació científica estigui present a les aules, i per això cal que els infants s'exercitin en l'ús de les habilitats comunicatives que usa la ciència.

Les idees dels nens i nenes es poden expressar de maneres molt diverses: amb dibuixos, amb maquetes, amb gestos, amb paraules escrites o dites, etc. La ciència utilitza aquests mateixos modes d'expressió $\mathrm{i}$ d'altres com el llenguatge matemàtic o les simulacions informàtiques. En la comunicació d'idees podem tenir en compte el mode -escrit, oral, dibuix, etc.-, l'audiència -ells mateixos, altres nens, el mestre, altres adults-, els propòsits -contrastar idees, exposar resultats, etc.-. La comunicació ha de servir a algun propòsit i no cal que sigui rutinària. Cal aprendre a prendre notes i registres informals durant les activitats en el que podria ser una llibreta de camp, i cal ajudar a fer-ho perquè això no és habitual a les aules i és un hàbit que es pot introduir des que l'escriptura ja comença a ser fluida. També es pot aprendre a fer registres formals tot discutint les millors maneres de fer-los, tenint en compte les propostes que fan els mateixos infants al respecte, analitzant mostres de bones presentacions d'informació, etc.

També caldria discutir sobre les maneres de comunicar una informació particular a una audiència determinada, introduir tècniques de presentació de la informació a través de l'ensenyament de certes convencions i aportant exemples, fer assequibles referències $i$ exemples per poder millorar les presentacions d'informació, encoratjar-los a usar llibretes de notes informals i donar oportunitats de discutir les seves pròpies maneres d'enregistrar i presentar les dades.

- Estimular l'autoavaluació continuada dels mateixos aprenentatges

El coneixement científic és coneixement públic, i com a tal està sotmès a l'avaluació de la seva pertinença per part de la comunitat científica. En el cas de la ciència escolar, caldria tenir en compte aquest aspecte i considerar que els nens i nenes han de poder autoavaluarse, sabent descriure el propi procés d'evolució conceptual o procedimental, i han de coavaluar-se, essent capaços de valorar les idees dels seus companys i companyes.

\section{A tall de resum}

Del que s'ha dit es desprèn que el fet de plantejar-se com desenvolupar les idees i habilitats científiques dels nens i nenes hauria de ser el nucli principal de la preocupació dels mestres en l'ensenyament-aprenentatge de les ciències. Aquest desenvolupament passa almenys per: tenir clares les idees científiques que es volen treballar i formular-se-les d'una manera assequible als infants; explorar les idees dels nens i nenes en relació amb els temes que es volen treballar; proposar als nens i nenes que interactuïn amb fenòmens i objectes de la realitat, tant físicament com intel-lectualment; ajudar-los a donar sentit a l'evidència i a la informació recollida tot usant els procediments i les actituds més relacionats amb l'activitat científica; encoratjar els nens i nenes a avaluar les seves idees a la llum de les noves experiències i de l'evidència disponible.

Intentar analitzar quines d'aquestes coses són presents a les nostres aules i, si no hi són, pensar per què no hi són, podria ser un bon camí per anar transformant la nostra pròpia pràctica.

\section{Referències bibliogràfiques}

ARCÀ, M., GUIDONI, P. i MAZZOLI, P. Enseñar ciencia. Reflexiones para una educación científica de base. Edit. Paidós. Barcelona. 1990.

BERNAL, J. M. Renovación pedagógica y enseñanza de las ciencias. Medio siglo de propuestas y experiencias escolares (1882-1936). Edit. Biblioteca Nueva. Madrid. 2001.

DRIVER, R., GUESNE, E. i TIBERGHIEN, A. Ideas científicas en la infancia y la adolescencia. Edit. MEC/Morata. Madrid. 1989.

DRIVER, R. i altres. Dando sentido a la ciencia en secundaria. Investigaciones sobre las ideas de los niños. Edit. Visor. Madrid. 1999.

ECHEVARRÍA, J. Filosofía de la ciencia. Edit. Akal. Madrid. 1995.

FREIRE, P. A la sombra de este árbol. Edit. El roure. Barcelona. 1997.

HARLEN, W. Enseñanza y aprendizaje de las ciencias. Edit. Morata. Madrid. 1998.

HARLEN, W. The teaching of science in primary schools. Edit. David Fulton Publishers. 3rd. edition. London. 2000.

MÁRQUEZ, C. i altres. La construcción de modelos explicativos complejos mediante preguntas mediadoras. "Investigación en la Escuela», 53 (2004) 71-81.

NIFFIELD FOUNDATION. Understanding science ideas. A guide for primary teachers. Edit. Collins Educational. London. 1997.

OSBORNE, R. i FREYBERG, P. El aprendizaje de las ciencias. Influencias de las ideas previas de los alumnos. Edit. Narcea. Madrid. 1995.

PUJOL, R.M. Didáctica de las ciencias en la educación primaria. Edit. Síntesis. Madrid. 2003.

REES, M. Nuestro hábitat cósmico. Edit. Paidós. BarceIona. 2002.

SPACE RESEARH REPORTS (1990-1998).

WAGENSBERG, J. La rebelión de las formas. Edit. Tusquets. Barcelona. 2004. 